DOI: 10.1002/anie.200601463

\section{A Ruthenium Complex with Superhigh Light-Harvesting Capacity for Dye-Sensitized Solar Cells**}

\author{
Chia-Yuan Chen, Shi-Jhang Wu, Chun-Guey Wu,* \\ Jian-Ging Chen, and Kuo-Chuan Ho
}

A dye-sensitized solar cell (DSSC) using Ru complexes as a photosensitizer was first reported by O'Regan and Grätzel in $1991 .^{[1]}$ The low-cost, easy preparation make DSSC one of the most promising photovoltaic cells for conversion of sunlight to electricity. Numerous sensitizers have been prepared, and their performance has been tested. ${ }^{[2-10]}$ A conversion efficiency of up to $11 \%$ was achieved by using cis-di(thiocyanato)bis(2,2'-bipyridyl-4,4'-dicarboxylate)ruthenium(II) (N3) as a photosensitizer. ${ }^{[11-12]}$ However, the conversion efficiency of DSSCs is still lower than that of the silicon-based photovoltaic cells. To obtain a high conversion efficiency, optimization of the short-circuit photocurrent $\left(I_{\mathrm{sc}}\right)$ and open-circuit potential $\left(V_{\text {oc }}\right)$ of the cell is essential. The value of $V_{\text {oc }}$ depends on the edge of conduction band in $\mathrm{TiO}_{2}$ and the redox potential of $\mathrm{I}^{-} /$ $\mathrm{I}_{3}^{-}$, otherwise $I_{\text {sc }}$ is related to the interaction between $\mathrm{TiO}_{2}$ and the sensitizer as well as the absorption coefficient of the sensitizer. The conduction band of $\mathrm{TiO}_{2}$ was known to have a Nernstian dependence on $\mathrm{pH}^{\left[{ }^{[13-14]}\right.}$ Thus, the molecular engineering of the ruthenium complexes for achieving the

[*] C.-Y. Chen, S.-J. Wu, Prof. C.-G. Wu

Department of Chemistry

National Central University

Jung-Li, Taiwan 32054 (Republic of China)

Fax: $(+886)$ 3-422-7664

E-mail: t610002@cc.ncu.edu.tw

J.-G. Chen, Prof. K.-C. Ho

Department of Chemical Engineering

National Taiwan University

Taipei, 10617, Taiwan (Republic of China)

[***] This work was financially supported by the National Science Council, Taiwan.

$\square$ Supporting information for this article is available on the WWW under http://www.angewandte.org or from the author. highest efficiency was attempted to increase the molar absorption coefficient and reduce the number of protons on the complexes. 4,4'-Dicarboxylic acid-2,2'-bipyridine (dcbpy) has been considered as the best anchoring ligand in $\mathrm{Ru}$ sensitizers. ${ }^{[15]}$ Finding new metal-complex sensitizers with higher conversion efficiency was achieved by modifying one of the anchoring ligands. Replacement of one of the dcbpy anchoring ligands with a highly conjugated ancillary ligand represents a molecular engineering approach for increasing the absorption coefficient and therefore the photocurrent density of the sensitizers as reported by Grätzel and coworkers. ${ }^{[16-20]}$ Herein, we report a new ruthenium photosensitizer CYC-B1 in which one of the dcbpy ligands in N3 was replaced with abtpy, a bipyridine ligand substituted with alkyl bithiophene groups. CYC-B1 has the highest absorption coefficient among the Ru-based photosensitizers used in DSSCs, and its power-conversion efficiency is $10 \%$ higher than that of $\mathbf{N} 3$ under the same cell fabrication and measuring procedures carried out in our laboratory.

CYC-B1 was prepared in a typical one-pot synthesis, ${ }^{[20]}$ and its structure (Scheme 1) was identified from NMR

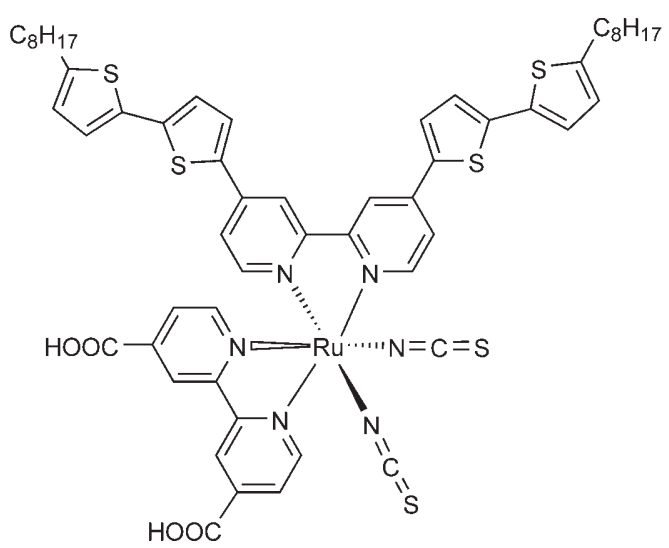

Scheme 1. The structure of CYC-B1.

spectroscopy, mass spectrometry, and elemental analysis. The electronic absorption spectra of the free dcbpy and abtpy ligands, CYC-B1, and N3 in DMF are displayed in Figure 1, and the optical data are summarized in Table 1. The absorption maximum $\left(\lambda_{\max }\right)$ assigned to the $\pi-\pi^{*}$ transition for dcbpy and abtpy are $299 \mathrm{~nm}$ and $375 \mathrm{~nm}$, respectively. The absorption maximum of abtpy is red-shifted by $76 \mathrm{~nm}$, which is attributed to its longer conjugation length, compared to that of dcbpy. The absorption spectrum of CYC-B1 shows three bands centered at $553 \mathrm{~nm}, 400 \mathrm{~nm}$, and $312 \mathrm{~nm}$. Based on comparison with the free abtpy ligand and the homoleptic complex N3, the absorption band at $312 \mathrm{~nm}$ for CYC-B1 is assigned to the intraligand $\pi-\pi^{*}$ transitions of dcbpy. The band centered at $400 \mathrm{~nm}$ contains two components: the $\pi-\pi^{*}$ transition of the abtpy ligand and one of the metal-to-ligand charge transfer (MLCT) transitions for CYC-B1. The $\pi-\pi^{*}$ transition of abtpy has a higher contribution since this band has a much stronger absorption coefficient than the corresponding band observed in N3. The absorption band at $553 \mathrm{~nm}$ is the characteristic MLCT transition for determining 


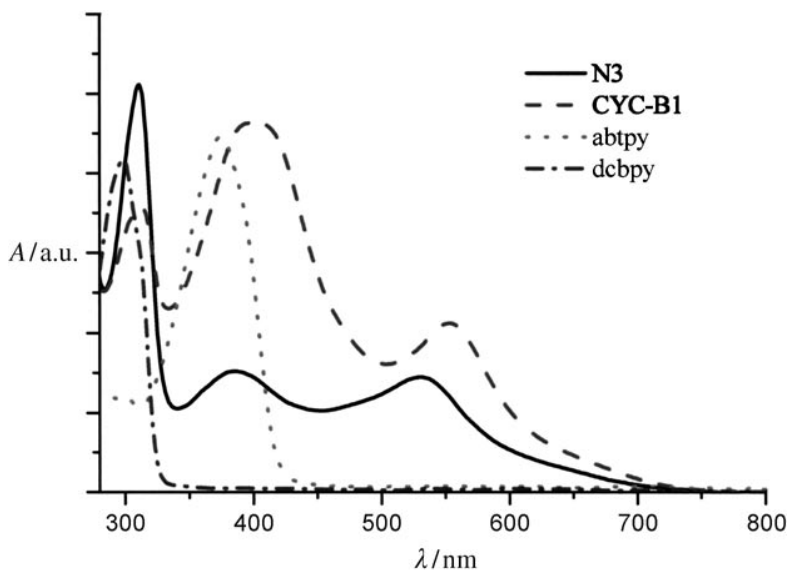

Figure 1. UV/Vis absorption spectra of dcbpy, abtpy, N3, and CYC-B1 in DMF.

the conversion efficiency of CYC-B1. This MLCT band may come from one of the two different conjugated ligands in CYC-B1. However, the $\mathrm{COOH}$ substituents on the dcbpy anchoring ligand have a higher electron-withdrawing ability than the alkyl bithiophene substituents of the abtpy ancillary ligand. The LUMO of the dcbpy ligand has a lower energy than that of abtpy. ${ }^{[21]}$ Therefore, the lower-energy MLCT band in CYC-B1 corresponds to the charge transfer between the metal center and the dcbpy anchoring ligand. The absorption maxima of both MLCT bands in CYC-B1 are larger than those of $\mathbf{N} 3$, thus suggesting that the abtpy ligand has lifted the energy level of the metal center. Encouragingly, the molar absorption coefficient of the lower-energy MLCT band of CYC-B1 is very high, higher than all Ru-based dyes used in solar cells.

To confirm the identity of the lower-energy MLCT band in CYC-B1, the location of the HOMOs and LUMOs in CYC-B1 were calculated with a semiempirical computational method (ZINDO/1), ${ }^{[22-25]}$ and the results are displayed in Figure 2. It is known ${ }^{[26]}$ that the HOMO and HOMO-1 of $\mathbf{N 3}$ have amplitudes on the ruthenium center and the NCS ligands whereas its LUMO and LUMO +1 are localized homogeneously on the two dcbpy ligands, thus facilitating the injection of electrons from the excited $\mathrm{Ru}$ complex to $\mathrm{TiO}_{2}$. The locations of HOMO and HOMO-1 in CYC-B1 are similar to those of $\mathbf{N 3}$, mainly on the metal center and NCS ligands. However, the LUMO is located only on the dcbpy anchoring ligand through which the excited electrons are directly transferred to $\mathrm{TiO}_{2}$. These results suggest that CYC-
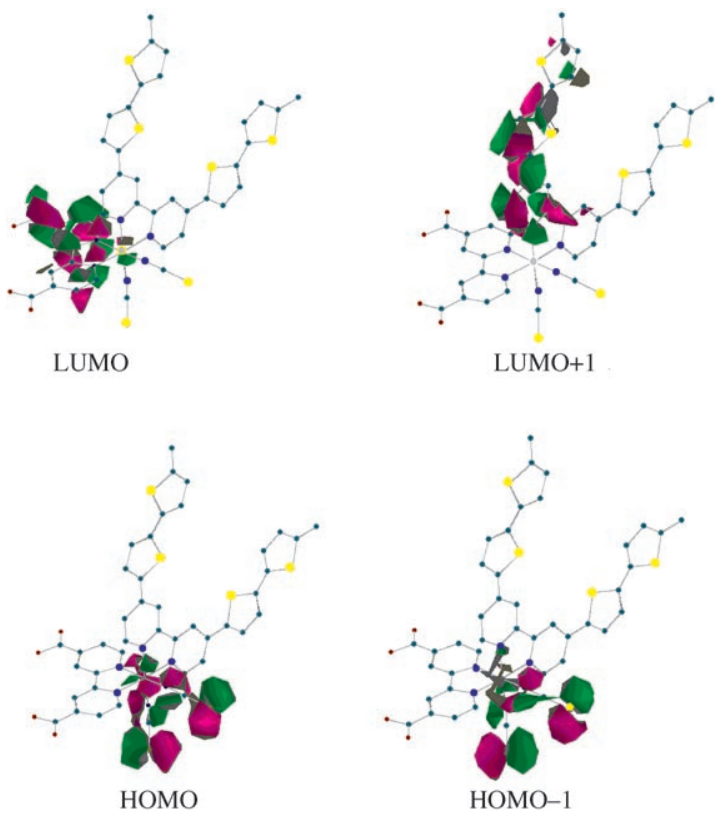

Figure 2. Graphical representation of the frontier orbitals of CYC-B1 (O red, $\mathrm{S}$ yellow, $\mathrm{C}$ green, $\mathrm{N}$ blue, Ru gray).

B1 is better than $\mathbf{N 3}$ as a photosensitizer for DSSCs, since both dcbpy ligands on $\mathbf{N 3}$ cannot bind to $\mathrm{TiO}_{2}$ particles simultaneously and the excited electron in the moiety that is not directly connected to $\mathrm{TiO}_{2}$ provides a very small contribution to the conversion efficiency of the DSSCs. Furthermore, for a high-efficiency sensitizer in DSSCs, the energy level of its LUMO should be well-matched with the lower limit of the conduction band in $\mathrm{TiO}_{2}$, and its $\mathrm{HOMO}$ should be sufficiently low in energy to accept electrons from the redox electrolyte such as $\mathrm{I}^{-} / \mathrm{I}_{3}{ }^{-}$. The energy level of the frontier orbitals for CYC-B1 that was established from the electrochemical and absorption data is also listed in Table 1. It was found that the energy levels of the HOMO and LUMO for CYC-B1 match well with the redox potential of $\mathrm{I}^{-} / \mathrm{I}_{3}{ }^{-}$and the LUMO of $\mathrm{TiO}_{2}$. Therefore, the higher molar absorption coefficient of CYC-B1 can be expected to have a better conversion efficiency than $\mathbf{N 3}$.

The monochromatic incident photon-to-current conversion efficiency (IPCE) and characteristic photocurrent density versus voltage curves for CYC-B1- and N3-based cells are illustrated in Figure 3, and the detailed parameters of the devices are also included in Table 1. The broad IPCE curve for CYC-B1 covers almost the entire visible spectrum from

Table 1: Physical data and performance of CYC-B1- and N3-sensitized cells.

\begin{tabular}{|c|c|c|c|c|c|c|c|c|c|c|}
\hline \multirow[b]{2}{*}{ Complex } & \multicolumn{3}{|c|}{$\varepsilon\left[\times 10^{4} \mathrm{M}^{-1} \mathrm{~cm}^{-1}\right]\left(\lambda_{\max }[\mathrm{nm}]\right)$} & \multirow{2}{*}{$\begin{array}{l}E_{\mathrm{ox}}^{[\mathrm{a}]} \text { of } \mathrm{Ru}^{\mathrm{III} / \mathrm{ll}} \\
{\left[\mathrm{V} \text { vs. } \mathrm{Fc} / \mathrm{Fc}^{+}\right]}\end{array}$} & \multirow{2}{*}{$\begin{array}{l}E_{\mathrm{HOMO}^{[\mathrm{b}]}} \\
{[\mathrm{eV}]}\end{array}$} & \multirow{2}{*}{$\begin{array}{l}E_{\text {LUMO }} \\
{[\mathrm{eV}]}\end{array}$} & \multicolumn{4}{|c|}{ Cell performance } \\
\hline & $\pi-\pi^{*}$ & $\pi-\pi^{*}$ or $4 d-\pi^{*}$ & $4 d-\pi^{*}$ & & & & $I_{\mathrm{sc}}\left[\mathrm{mAcm}^{-2}\right]$ & $V_{\text {oc }}[\mathrm{V}]$ & $F F$ & $\eta[\%]$ \\
\hline CYC-B1 & $3.58(312)$ & $4.64(400)$ & $2.12(553)$ & 0.30 & 5.10 & 3.52 & 23.92 & 0.65 & 0.55 & 8.54 \\
\hline N3 & $5.11(311)$ & $1.52(385)$ & $1.45(530)$ & 0.40 & 5.20 & 3.52 & 21.32 & 0.66 & 0.54 & 7.70 \\
\hline
\end{tabular}

[a] The $\mathrm{Ag} / \mathrm{AgNO}_{3}$ reference electrode was calibrated with a ferrocene/ferrocinium $\left(\mathrm{Fc} / \mathrm{Fc}^{+}\right.$) redox couple. The electrochemical experiments were carried out in $0.1 \mathrm{M}\left[n \mathrm{Bu}_{4} \mathrm{~N}\right] \mathrm{BF}_{4} / \mathrm{DMF}$ solution. [b] The absorption onset of each complex was used to calculate the energy gap and the frontier orbitals. The energy levels of the $\mathrm{HOMO}$ and LUMO were calculated with the following formulas: $E_{\mathrm{HOMO}}=E_{\mathrm{ox}}-E_{\mathrm{Fc} / \mathrm{Fc}+}+4.8 \mathrm{eV} ; E_{\mathrm{LUMO}}=E_{\mathrm{HOMO}}-E_{\mathrm{g}} ; E_{\mathrm{g}}=$ absorption threshold of the Ru complexes. 


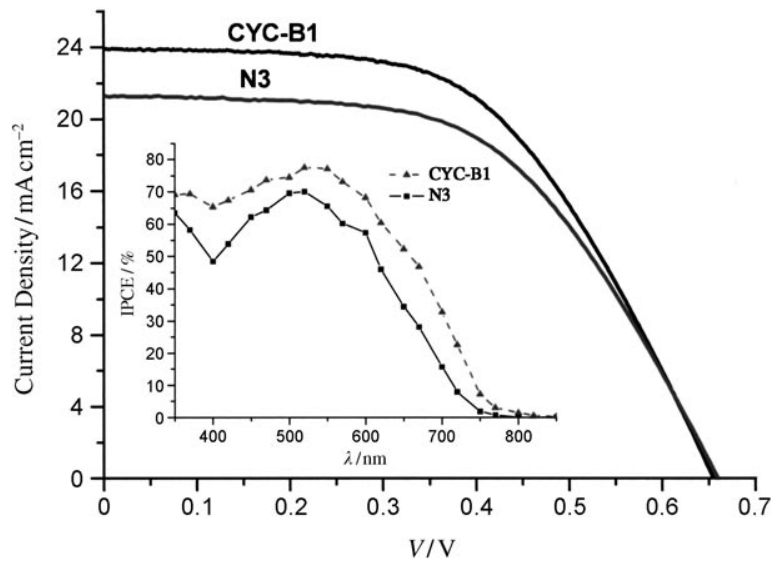

Figure 3. Current density vs. voltage characteristic of photovoltaic devices with N3 and CYC-B1 as sensitizers under AM 1.5 simulated sunlight $\left(100 \mathrm{~mW} \mathrm{~cm}^{-2}\right)$ illumination; inset: the typical photocurrentaction spectra of the photovoltaic devices (thickness of $\mathrm{TiO}_{2}: 20 \mu \mathrm{m}$; cell active area: $0.25 \mathrm{~cm}^{2}$ ).

350 to $700 \mathrm{~nm}$ with a maximum of $77.5 \%$. Unlike the $\mathbf{N 3}$ cell, the IPCE curves for the CYC-B1 cell are not consistent with its absorption spectrum in DMF. The band centered at $400 \mathrm{~nm}$, which mainly comes from the abtpy intraligand $\pi-\pi^{*}$ transitions, has a smaller contribution to the photon-tocurrent conversion efficiency. Under AM1.5 sunlight illumination $\left(100 \mathrm{~mW} \mathrm{~cm}^{-2}\right)$, the CYC-B1-sensitized solar cell gave a power-conversion efficiency $(\eta)$ of $8.54 \%$, which is $10 \%$ higher than that of the $\mathbf{N 3}$-sensitized cell under the same cell fabrication and measuring procedures. Both the $V_{\mathrm{oc}}$ and $F F$ values of the CYC-B1-sensitized cell are close to those of the N3-sensitized cell. The higher $\eta$ value of the CYC-B1 cell (compared to the $\mathbf{N} 3$ cell) comes from the higher $I_{\mathrm{sc}}$ value, which is mainly attributed to the high absorption coefficient of the MLCT band for dcbpy. Furthermore, the objective of this work is to find the best photosensitizer for DSSCs. The alkyl group on the abtpy ancillary ligand can prevent the complexes from water-induced desorption of the dye molecules from the $\mathrm{TiO}_{2}$ surface. ${ }^{[27]}$ We could anticipate that DSSCs sensitized with CYC-B1 may also exhibit good stability.

Enhancing the absorption coefficient of the MLCT band by increasing the conjugation length of the ancillary ligand is a known strategy. ${ }^{[16-20]}$ What is so special about the alkyl bithiophene group compared to other substituents (such as phenylenevinylene) that have already been reported $?^{[18,19]}$ It is known ${ }^{[28]}$ that a polythiophene moiety can be regarded as a cis-polyacetylene chain bridged with sulfur atoms. The "bridging sulfur atoms" could effectively provide aromatic stability to the polyacetylene chain while preserving the desirable physical properties such as high charge transport. The facile functionalization of thiophene groups also offers relatively efficient synthetic solutions to solubility, polarity, and band-gap tuning. Furthermore, sulfur has greater radial extension in its bonding than the second-row elements such as carbon. Therefore, thiophene is a more electron-rich moiety; incorporation of thiophene onto bipyridine ligands can raise the energy levels of the metal center and the LUMO of the ligands. ${ }^{[29]}$ As a consequence, the band resulting from charge transfer from the metal center to the anchoring ligand is redshifted, and upon illumination of the sample the electrons on the metal center are transferred to the anchoring dcdpy ligand where electrons can move to the outer circuit through the $\mathrm{TiO}_{2}$ particles more efficiently. These results account for the high current density of the CYC-B1-sensitized cell.

In this study we found a way to improve the powerconversion efficiency of DSSCs by molecular engineering of an Ru-based photosensitizer. The CYC-B1 compound reported herein is a representative ruthenium complex with high current density and conversion efficiency. We believe that ruthenium-based DSSCs with even higher efficiency can be obtained by fine-tuning the structure of the ruthenium complexes.

\section{Experimental Section}

CYC-B1 was prepared in a typical one-pot synthesis ${ }^{[2,30]}$ by using the new ligand abtpy, which was devised and prepared in our laboratory. LRMS (FAB): calcd $m / z: 1170.17$; found: $1170.2(\mathrm{~m})[\mathrm{M}]^{+}, 1112.2$ (s) $[M-\mathrm{NCS}]^{+} ;{ }^{1} \mathrm{H} \mathrm{NMR} \quad\left(500 \mathrm{MHz}, \quad\left[\mathrm{D}_{6}\right] \mathrm{DMSO}\right.$, atom-numbering scheme is provided in the Supporting Information): $\delta=9.49\left(\mathrm{~d}, \mathrm{H}^{6}\right.$, $J=5.7 \mathrm{~Hz}), 9.15\left(\mathrm{~d}, \mathrm{H}^{6^{\prime}}, J=5.7 \mathrm{~Hz}\right), 9.10\left(\mathrm{~s}, \mathrm{H}^{3}\right), 8.96\left(\mathrm{~s}, \mathrm{H}^{3^{\prime}}\right), 8.94(\mathrm{~s}$, $\left.\mathrm{H}^{3^{\prime \prime}}\right), 8.80\left(\mathrm{~s}, \mathrm{H}^{3^{\prime \prime \prime}}\right), 8.32\left(\mathrm{~d}, \mathrm{H}^{5}, J=5.7 \mathrm{~Hz}\right), 8.19\left(\mathrm{~d}, \mathrm{H}^{6^{\prime \prime}}, J=3.8 \mathrm{~Hz}\right)$, $8.11\left(\mathrm{~d}, \mathrm{H}^{5^{\prime}}, J=5.7 \mathrm{~Hz}\right), 7.99\left(\mathrm{~d}, \mathrm{H}^{5^{\prime \prime}}, J=3.8 \mathrm{~Hz}\right), 7.95\left(\mathrm{~d}, \mathrm{H}^{6^{\prime \prime \prime}}, J=\right.$ $5.9 \mathrm{~Hz}), 7.64\left(\mathrm{~d}, \mathrm{H}^{5^{\prime \prime \prime}}, J=5.9 \mathrm{~Hz}\right), 7.47\left(\mathrm{~d}, \mathrm{H}^{9^{\prime \prime}}, J=3.7 \mathrm{~Hz}\right), 7.37\left(\mathrm{~d}, \mathrm{H}^{9^{\prime \prime \prime}}\right.$, $J=6.8 \mathrm{~Hz}), 7.35\left(\mathrm{~d}, \mathrm{H}^{10^{\prime \prime}}, J=3.7 \mathrm{~Hz}\right), 7.31\left(\mathrm{~d}, \mathrm{H}^{14^{\prime \prime}}, J=3.4 \mathrm{~Hz}\right), 7.28(\mathrm{~d}$, $\left.\mathrm{H}^{10^{\prime \prime \prime}}, J=6.8 \mathrm{~Hz}\right), 7.21\left(\mathrm{~d}, \mathrm{H}^{15^{\prime \prime}}, J=3.4 \mathrm{~Hz}\right), 6.86\left(\mathrm{~d}, \mathrm{H}^{14^{\prime \prime \prime}}, J=3.4 \mathrm{~Hz}\right)$, $6.80\left(\mathrm{~d}, \mathrm{H}^{15^{\prime \prime \prime}}, J=3.4 \mathrm{~Hz}\right), 2.79(\mathrm{t}, 2 \mathrm{H}), 2.74(\mathrm{t}, 2 \mathrm{H}), 1.61(\mathrm{t}, 2 \mathrm{H}), 1.57$ $(\mathrm{t}, 2 \mathrm{H}), 1.23(\mathrm{~m}, 20 \mathrm{H}), 0.85(\mathrm{t}, 3 \mathrm{H}), 0.83 \mathrm{ppm}(\mathrm{t}, 3 \mathrm{H})$. Elemental analysis (\%) calcd for $\mathrm{C}_{56} \mathrm{H}_{56} \mathrm{~N}_{6} \mathrm{O}_{4} \mathrm{~S}_{6} \mathrm{Ru}$ : C 57.46, H 4.82, N 7.18, S 16.44; found: C 55.14, H 5.05, N 6.81, S 15.44. The detailed procedures for synthesis and characterization of the ligand and complex as well as the DSSC fabrication and measuring conditions can be found in the Supporting Information.

Received: April 13, 2006

Revised: June 7, 2006

Published online: July 25, 2006

Keywords: charge transfer - conjugation - dyes/pigments . photosensitizers r ruthenium

[1] B. O’Regan, M. Grätzel, Nature 1991, 353, 737.

[2] M. K. Nazeeruddin, P. Péchy, T. Renouard, S. M. Zakeeruddin, R. Humphry-Baker, P. Comte, P. Liska, L. Cevey, E. Costa, V. Shklover, L. Spiccia, G. B. Deacon, C. A. Bignozzi, M. Grätzel, J. Am. Chem. Soc. 2001, 123, 1613.

[3] A. Islam, H. Sugihara, M. Yanagida, K. Hara, G. Fujihashi, Y. Tachibana, R. Katoh, S. Murata, H. Arakawa, New J. Chem. 2002, 26, 966

[4] P. Wang, R. H. Baker, J. E. Moser, S. M. Zakeeruddin, M. Grätzel, Chem. Mater. 2004, 16, 3246.

[5] S. Altobello, R. Argazzi, S. Caramori, C. Contado, S. Da Fré, P. Rubino, C. Choné, G. Larramona, C. A. Bignozzi, J. Am. Chem. Soc. 2005, 127, 15342.

[6] K. Hara, M. Kurashige, Y. Dan-oh, C. Kasada, A. Shinpo, S. Suga, K. Sayama, H. Arakawa, New J. Chem. 2003, 27, 783.

[7] T. Horiuchi, H. Miura, K. Sumioka, S. Uchida, J. Am. Chem. Soc. 2004, 126, 12218.

[8] T. Kitamura, M. Ikeda, K. Shigaki, T. Inoue, N. A. Anderson, X. Ai, T. Lian, S. Yanagida, Chem. Mater. 2004, 16, 1806. 
[9] M. K. Nazeeruddin, R. Humphry-Baker, D. L. Officer, W. M. Campbell, A. K. Burrell, M. Grätzel, Langmuir 2004, 20, 6514.

[10] Q. Wang, W. M. Campbell, E. E. Bonfantani, K. W. Jolley, D. L. Officer, P. J. Walsh, K. Gordon, R. Humphry-Baker, M. K. Nazeeruddin, M. Grätzel, J. Phys. Chem. B 2005, 109, 15397.

[11] M. K. Nazeeruddin, A. Kay, L. Rodicio, R. Humphry-Baker, E. Müller, P. Liska, N. Vlachopoulos, M. Grätzel, J. Am. Chem. Soc. 1993, 115, 6382 .

[12] M. Grätzel, J. Photochem. Photobiol. A 2004, 164, 3.

[13] S. Yan, J. T. Hupp, J. Phys. Chem. 1996, 100, 6867.

[14] T. Watanabe, A. Fujishima, O. Tatsuoki, K. Honda, Bull. Chem. Soc. Jpn. 1976, 49, 8.

[15] M. Yanagida, L. P. Singh, K. Sayama, K. Hara, R. Katoh, A. Islam, H. Sugihara, H. Arakawa, M. K. Nazeeruddin, M. Grätzel, J. Chem. Soc. Dalton Trans. 2000, 2817.

[16] H. Sugihara, L. P. Singh, K. Sayama, H. Arakawa, Md. K. Nazeeruddin, M. Grätzel, Chem. Lett. 1998, 10, 1005.

[17] T. Renouard, R.-A. Fallahpour, Md. K. Nazeeruddin, R. Humphry-Baker, S. I. Gorelsky, A. B. P. Lever, M. Grätzel, Inorg. Chem. 2002, 41, 367.

[18] P. Wang, S. M. Zakeeruddin, J.-E. Moser, R. Humphry-Baker, P. Comte, V. Aranyos, A. Hagfeldt, M. K. Nazeeruddin, M. Grätzel, Adv. Mater. 2004, 16, 1806.

[19] P. Wang, C. Klein, R. Humphry-Baker, S. M. Zakeeruddin, M. Grätzel, J. Am. Chem. Soc. 2005, 127, 808.

[20] C. Klein, Md. K. Nazeeruddin, P. Liska, D. Di Censo, N. Hirata, E. Palomares, J. R. Durrant, M. Grätzel, Inorg. Chem. 2005, 44, 178.

[21] Z. Yang, I. Sokolik, F. E. Karasz, Macromolecules 1993, 26, 1188.

[22] H. Rensmo, S. Södergren, L. Patthey, K. Westmark, L. Vayssieres, O. Khole, P. A. Brühwiler, A. Hagfeldt, H. Siegbahn, Chem. Phys. Lett. 1997, 274, 51.

[23] M. K. Nazeeruddin, S. M. Zakeeruddin, R. Humphry-Baker, S. I. Goreslky, A. B. P. Lever, M. Grätzel, Coord. Chem. Rev. 2000, 208, 213

[24] T. Renouard, R. A. Fallahpour, M. K. Nazeeruddin, R. Humphry-Baker, S. I. Gorelsky, A. B. P. Lever, M. Grätzel, Inorg. Chem. 2002, 41, 367.

[25] E. Figgemeier, V. Aranyos, E. C. Constable, R. W. Handel, C. E. Housecroft, C. Risinger, A. Hagfeldt, E. Mukhtar, Inorg. Chem. Commun. 2004, 7, 117.

[26] N. Hirata, J.-J. Lagref, E. J. Palomares, J. R. Durrant, M. K. Nazeeruddin, M. Grätzel, D. Di Censo, Chem. Eur. J. 2004, 10, 595.

[27] P. Wang, S. M. Zakeeruddin, J.-E. Moser, M. K. Nazeeruddin, T. Sekiguchi, M. Grätzel, Nat. Mater. 2003, 2, 402.

[28] J. D. Tovar, A. Rose, T. M. Swager, J. Am. Chem. Soc. 2002, 124, 7762.

[29] S. S. Zhu, R. P. Kingsborough, T. M. Swager, J. Mater. Chem. 1999, 9, 2123.

[30] C.-Y. Chen, H.-C. Lu, C.-G. Wu, J.-G. Chen, K.-C. Ho, $A d v$. Funct. Mater. 2006, in press. 